\title{
MIEDOS Y COSTUMBRES CAMPESINAS COMO OBSTÁCULOS AL PROGRESO DE UNA NACIÓN. LO CIVILIZABLE E INCIVILIZABLE EN LAS ILUSTRACIONES DE LOS CUENTOS DE MANUEL JosÉ OTHÓN
}

\author{
Una mirada al campesinado porfiriano visto por la élite
}

Fears and Customs from the Peasants as Obstacles to the Progress of a Nation: the Civilized and the Not Civilized in the Illustrations from the Tales of Manuel José Othón

\author{
Diana Hernández Castillo
}

Universidad Autónoma Metropolitana, México

\begin{tabular}{l} 
KEY WORDS \\
\hline Manuel José Othón \\
Civilized \\
Not Civilized \\
Fears and Customs \\
Obstacles \\
Illustrations
\end{tabular}

PALABRAS CLAVE

Manuel José Othón

Civilizable

Incivilizable

Miedos y costumbres

Obstáculos

Ilustraciones

\begin{abstract}
In this work, we analyze the illustrated tales "Coro de Brujas", "El nahual" and "Encuentro pavoroso" by the writer and politician Manuel José Othón (1858 - 1906). We have identified how the author detailed, represented and revealed the popular figures of the Porfirian peasantry and their fears, superstitions and customs as obstacles to progress. We also examine the modernizing sense that seeks to civilize peasants, embodied in male characters that act as local authorities. Thus, from a historical, historiographic and literary perspective, different peculiarities present in the construction of Mexico as a nation can be identified in Othón's work.
\end{abstract}

RESUMEN

En esta investigación analizamos los cuentos ilustrados "Coro de brujas", "El nahual" y "Encuentro pavoroso" del escritor y político Manuel José Othón (1858-1906). Detectamos cómo el autor detalló, representó y expuso las figuras populares del campesinado porfiriano, los mendigos, el miedo, las supersticiones y las costumbres vernáculas como obstáculos al progreso. Asimismo, examinamos el sentido modernizador que busca civilizar a los labriegos, encarnado en personajes masculinos que fungen como autoridades locales. Así, desde una perspectiva histórica, historiográfica y literaria se pueden estudiar diversas particularidades que estuvieron presentes en la construcción de México como nación.

Recibido: 28/05/2019

Aceptado: 12/08/2019 


\section{Introducción}

$\mathrm{M}$ anuel José Othón fue un escritor de los siglos XIX y XX que incursionó en la narrativa, la dramaturgia y la lírica. Sus poemas han sido objeto de estudios varios (véase por ejemplo: Reyes, 1910 y Leal, 1958), lo que ha relegado sus cuentos y novelas. No obstante, si nos enfocamos a los estudios recientes sobre este autor, es posible determinar que se analiza su ambiente, la naturaleza y el paisaje, su biografía, sus influencias, vida personal e intelectual, así como algunos elementos específicos en sus novelas y cuentos (veáse Hernández, 2018; Hernández, 2019a; Hernández, 2019b; Montejano y Aguiñaga, 2001; Anaya, 1999; Betancourt, 2016; González, s/f).

En este sentido, nos hemos adentrado en la narrativa del autor desde una perspectiva histórica que logre hacernos ver aquellas particularidades y generalidades presentes en el autor, reflejo de su pasado, su contexto histórico, de su realidad inmediata, de sus deseos y expectativas. Así, partimos del supuesto de que, en la lógica del progreso y el orden del siglo XIX, la élite buscó controlar a los estratos sociales considerados más nocivos y peligrosos en un momento en el que permeaban las ideas de fobia y exclusión a dichos sectores. Ello también trastocó a la literatura. En las obras de Othón hemos detectado que percibe en el campesinado porfiriano agentes sociales a civilizar; se los considera como seres bárbaros, poco inteligentes y supersticiosos en exceso; en consecuencia, son sus miedos y costumbres "expresión de una experiencia real y vivida" (Peñalosa, 1995: 24) elementos que se transforman obstáculos al progreso en territorio mexicano y, por tanto, deben erradicarse. Para ello se retomarán tres cuentos: "Coro de brujas", "El nahual" y "Encuentro pavoroso".

Así nuestros objetivos son: analizar la intromisión del progreso en personajes que poseen jerarquías; determinar lo civilizable e incivilizable en la sociedad rural que Othón observó; demostrar que las costumbres campesinas y el miedo son obstáculos para la construcción de la nación mexicana y examinar el sentido modernizador, encarnado en figuras masculinas, que buscan civilizar en los textos e ilustraciones de los cuentos mencionados. Metodológicamente analizamos sus obras para ahondar en los acontecimientos sociohistóricos presentes en el autor. De esta manera, nuestra metodología alude a la investigación histórica y documental para estudiar su narrativa (Lanson, 2003b: 195-196) rescatando el contexto histórico y el mundo del autor. El marco teórico -el cual fue desarrollado a lo largo del artículo- alude a conceptos como la modernización y el progreso (Eumed, s/f, s/p; Koselleck, 1993). También retomamos la bestialización y animalización, así como lo civilizable e incivilizable como aquellos conceptos existentes dentro del saber preconcebido presente en el imaginario colectivo del siglo XIX y principios del XX mismos que -de cierta manera- el autor definió en sus adjetivos y calificativos para designar a sus personajes, los cuales están entendidos también bajo el eje que atañe al biopoder (París Pombo, 2009: 199; Mendieta, 2007: 144-145; Foucault, 2008: 346-347) ya que Othón, como político del siglo XIX y principios del XX, difundió "las ideas de Spencer y del darwnismo social" (París Pombo, 2009: 199) en sus obras. Para el análisis de las imágenes nos hemos basado en la descripción detallada de cada una (lo que es visible) en torno a sus personajes. En base a esto, hemos titulado las ilustraciones nosotros mismos pues en el texto no se ha detectado título alguno. De esta manera, logramos resaltar los elementos observables: ademanes, gestos, posiciones corporales, vestimenta y objetos propios de cada sector social, por mencionar algunos. Lo anteriormente señalado otorga un mayor soporte al "tratamiento histórico" (Lanson, 2003a: 178-180) de los cuentos de Othón, ya que es lo que nosotros, desde el enfoque histórico, hemos experimentado con las lecturas y relecturas (Alatorre, 1973: 1) de la narrativa e imágenes del autor.

Concluimos advirtiendo que el potosino en sus obras manifestó, de manera textual y visual, las ideas que tenía de dicha sociedad rural. Ello permitió determinar elementos modernizadores que dejaron entrever las particularidades que existieron durante el Porfiriato, así como en ese proceso de construcción de la nación mexicana.

\section{El Porfiriato: breve contexto histórico}

Para analizar al autor y sus obras es menester elaborar una breve síntesis histórica. El Porfiriato fue un período en donde existió un crecimiento económico, industrial y una modernización, ésta última categoría la entendemos como un proceso de cambio económico, político, social y cultural derivado de la industrialización, que conlleva al progreso (véase Eumed, s/f, s/n). De esta manera, se vieron beneficiados el sector medio, los rancheros adinerados y los peones del norte de México (Katz y Lomnitz, 2011: 23-26). Bajo las premisas de progreso, modernidad e industrialización, las élites mexicanas buscarían simular modos y costumbres extranjeros en pro de una sociedad más higiénica, más embellecida y lo harían "poniendo orden a todo aquello que no lo tenía" (Uribe, 2016: 13). Ello contemplaba también a los sectores sociales considerados nocivos y peligrosos: los pobres, los viciosos y los marginados quienes al poseer estos males que desembocaban en la indecencia "decantaron en el surgimiento de 
nuevos reglamentos para normar y controlar" (Uribe, 2016: 14).

El estado de San Luis Potosí no fue la excepción, su élite gobernante buscaría entonces "modernizar y embellecer" (Uribe, 2016: 47-66). Entre sus preocupaciones estaban la necesidad de higienizar a los sectores sociales bajos, a quienes veían como bárbaros y poco inteligentes. Asimismo, poseían gran inquietud acerca de esa necesidad de erradicar lo que no era bien visto, un peligro que corría no sólo el estado, también la élite local (Uribe, 2016: 82-86). Cabe destacar que todos estos factores estuvieron presentes también en Othón y lo reflejaría en su producción literaria.

\section{Contextualizando (históricamente) a Manuel José Othón}

En el momento en que Othón redactó sus cuentos, 1903, estaba ceñido a un ambiente intelectual donde permeaba el romanticismo, el modernismo y el neoclasicismo. Además, era común que los autores combinaran géneros literarios (Granados, 2010: 21-23). Siendo Othón modernista, debemos señalar que el modernismo se cimentó no sólo con el romanticismo, sino también con otras literaturas en donde el potosino recurrió no sólo "a los clásicos latinos como una manera de ampliar la tradición española" (Granados, 2010: 42), también retomó la tradición alemana, prehispánica y mexicana (Wedel, 2000: s/p; Hernández, 2019b: s/p).

Durante la segunda mitad del siglo XIX, existió en México un ambiente propicio para la producción de una literatura ceñida a una necesidad de progreso y patriotismo, ideas mismas que ayudarían a cimentar la construcción de la nación (Easterling, 2011: 97-98). Asimismo, estaban latentes las premisas de la supuesta inferioridad racial de los indígenas, la idea de un pueblo poseedor de vicios e indecencia que lo desvirtuaban mientras que se mantenían alejados del interés por la vida socio-política y económica del país. De esta manera, clasismo, racismo y exclusión a los sectores sociales bajos (Katz y Lomnitz, 2011: 34-35) fueron ideologías presentes en el momento en que Othón escribió, pero también debemos señalar que su contexto familiar, su infancia e instrucción fueron elementos que también pueden ayudar a comprender estas visiones que poseía el autor hacia el pueblo. Othón, como su apellido lo indica, tenía descendencia alemana (Wedel, 2000: s/p), su padre administraba haciendas y fue un alumno brillante que redactaba versos desde edad temprana. Posteriormente ingresó a seminarios donde estudió latín, griego, humanidades, filosofía, abogacía y fue en estas instituciones que fue compañero de otros escritores importantes del siglo XIX (Montejano y Aguiñaga, 2001: 45-59). Lo anteriormente mencionado, permite comprender la presencia de estas visiones, propias de los estratos sociales altos, hacia el campesinado porfiriano.

Othón, desde que era muy joven, estuvo convivió en las haciendas familiares y creemos que era conocedor de la cotidianeidad de la vida rural. En este sentido, citamos a Peñalosa al mencionar que Othón "denuncia, en pleno porfirismo, de los abusos de los hacendados, amos y patronos contra los oprimidos campesinos" (Peñalosa, 1995: 8). En efecto, Othón denunció las prácticas de los hacendados y sí volteó la mirada al pueblo, pero suponemos todavía lo observa como un sector inferior al que ve con fobia y asco, ya que a menudo los metamorfosea en animales -domésticos como el ganado-: "[m]uchas veces alimentóse el pastor con maguey y nopal, como los bueyes" (Othón, 2016: 85) y en bestias, por ejemplo al referirse a las bajas pasiones de las mujeres comenta que se desencadenan debido a un "temperamento de bestia brava” (Othón, 2016: 90). De este modo, podemos reiterar que estos dos elementos, animalizar y bestializar, nos ayudan a clarificar los textos e imágenes del potosino dentro de lo que él determina como civilizable. Las bestias cuadrúpedas, pertenecientes al ganado, se pueden persuadir y domesticar aún si son observadas como seres irracionales. Así, podemos entender la notable reducción que hace el autor a sus personajes rurales, lo que conllevará a la destrucción, denigración y deshumanización de dichos individuos, animalizados $\mathrm{y}$ bestializados para determinar si se pueden, o no, domesticar. Es decir, acostumbrarlos a enseñarles las nuevas normas y reglamentos del progreso, civilizarlos para que trabajen el campo, o bien, por el contrario, inducirlos a la muerte porque son incivilizables. Recapitulando, en sus textos, Othón deja entrever los infortunios de los sectores desfavorecidos, siempre denotando su inferioridad. Por ejemplo, el potosino sentenció "satisfacían el hambre con hartura, única aspiración de los infortunados campesinos" (Othón, 2016: 82).

En los personajes del autor se han visualizado no sólo características de la sociedad porfiriana en México, sino también algunas de las necesidades socio-políticas y culturales de la época. En su narrativa encontramos la existencia de personajes con funciones judiciales o cargos que aluden a una notable jerarquía, quienes introducen una temporalidad donde pasado y futuro se instalan en el presente como experiencias y como expectativas (Koselleck, 1993: 338), dado que en sus textos se puede visualizar la intromisión del progreso en un poblado rural que civilice a los campesinos al mismo tiempo que acelere, perfeccione y modifique (Koselleck, 1993: 350-351) el tiempo rural en miras del progreso, pues cabe recordar que en "el porfiriato, casi todos los aparatos del Estado que operan en el ámbito rural están orientados, de una u 
otra forma, al control de los trabajadores agrícolas." (Bartra citado en Lutz, 2009: 154).

Gracias a que estas obras venían acompañadas de ilustraciones, podemos detectar la permanencia de estas figuras/personajes para determinar cómo se exhibieron y expusieron, ya que, de acuerdo con Simonson, detectamos una ficción de corte histórica en Othón, con personajes y situaciones históricamente creíbles (Simonson, 2004: 195-196) que pueden ser objeto de expectativas al estar situados dentro de un proyecto a futuro. Cabe destacar que antes de continuar consideramos necesario elaborar breves reseñas de los cuentos:

"Encuentro pavoroso": Este texto narra la travesía nocturna de un hombre, detallando el paisaje y las amenazas presentes en los territorios que debe atravesar. El narrador protagonista del cuento, cuyo nombre no se menciona, se adelanta en la jornada y deja al sirviente atrás. Conforme avanza la narración se apreciará su miedo y exaltación ante una lúgubre aparición, que, realidad, es un cadáver amortajado para presentarlo ante las autoridades. El jinete logrará reponerse ante tal "visión”, no así el mozo que atraviesa el camino solo; él morirá por no haberse sobrepuesto a "lo visto" inmerso en sus supersticiones (Othón, 2016: 13-23).

"Coro de brujas": En este cuento hallamos otro narrador protagonista, del cual tampoco se sabe su nombre, que acude al auxilio de un administrador de una hacienda, Policarpo o Don Carpio, quien es aquejado de maldiciones y brujerías. Con ayuda del personaje principal, el administrador logra hacer afrenta de los males que lo atormentan, sólo para darse cuenta de que eran las tretas elaboradas por la antigua pareja del administrador, quien se venga de él por haberla abandonado (Othón, 2016: 25-39).

"El nahual": El cuento detalla la afrenta de un narrador protagonista "anónimo" con las creencias campesinas acerca de los nahuales. Persigue a un coyote que roba la comida y el ganado de los campesinos, quienes aseguran que el animal es un nahual, un ente ligado al mal. Finalmente resulta ser un mendigo que amaestró al coyote (Othón, 2016: 41-56).

\section{El progreso como necesidad en "Coro de brujas"}

En este trabajo consideramos que el "progreso se dirigía a una transformación activa de este mundo" (Koselleck, 1993: 347). Dicho lo anterior, podemos concluir que el progreso está presente en personajes masculinos que pretenden transformar la vida de los habitantes gracias a su jerarquía y poderío local. Por consiguiente, son figuras autoritarias portadoras de modernidad que, mediante sus expectativas, vislumbran un posible "futuro hecho presente" (Koselleck, 1993: 338) para la nación. Y observan, al igual que Othón, "con desprecio a los grados inferiores de desarrollo de otros pueblos, por lo que el que se sabía superior en civilización se creía justificado para dirigirlos" (Koselleck, 1993: 346).

Derivado de ello, los narradores protagonistas son una constante de modernización y de aceleración del tiempo en un campesinado que, se sugiere, necesita ser civilizado para que no desaparezca dentro de la lógica del progreso y sea útil en la construcción de la nación, necesidades y problemáticas que Othón sabía al estar inmerso en la política (Easterling, 2011: 99). De esta manera, las imágenes que ilustraron los cuentos también introducen este elemento modernizador en el contexto inmediato del autor y de la opinión pública en El Mundo Ilustrado. Cabe destacar que el potosino demostró su satisfacción ante dichas imágenes al comentar que eran "bastante correctos" (Othón citado en Peñalosa, 1995: 19).

Figura 1. La visibilidad de los agentes del progreso

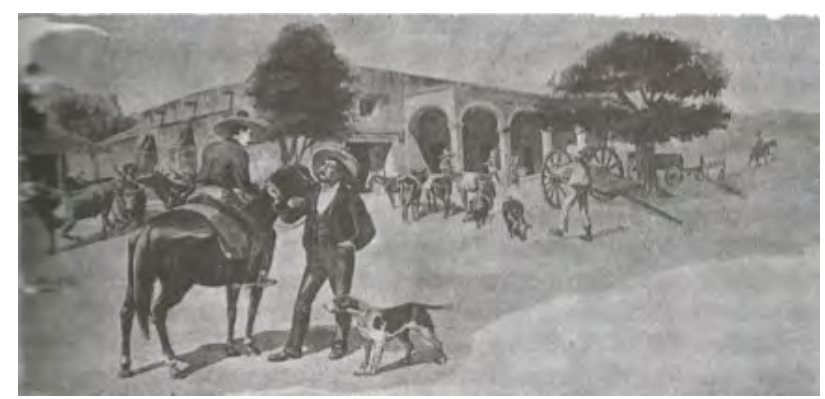

Fuente: adaptado de Othón, 2016: 25.

Esta primera imagen muestra a dos figuras masculinas sobresalientes que no son campesinos; la vestimenta y la postura los hace diferentes. Incluso el color de piel -más claro- en algunas ocasiones es visible, como se verá más adelante. Detrás de ellos, se encuentran los sirvientes, peones y labriegos. El caballo y el perro fiel, en esta ilustración, son elementos de progreso que poseen las figuras autoritarias, personajes que arriban a la hacienda para llevar la modernización consigo. Como se puede apreciar, Othón hace aparecer el campesinado a la lejanía, son apenas perceptibles, pero están presentes bajo su mirada y de esta manera los presenta para posteriormente desaparecerlos o bien, a que existan y pervivan como meros estereotipos, pues, de acuerdo con Georges Didi-Huberman "[l]os pueblos expuestos a la reiteración estereotipada de las imágenes son también pueblos expuestos a desaparecer." (DidiHuberman, 2014: 14). 
Figura 2. Razón vs superstición

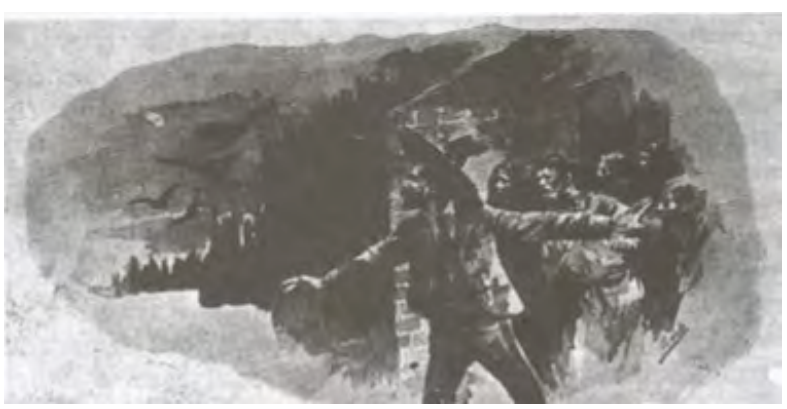

Fuente: adaptado de Othón, 2016: 30.

La segunda imagen muestra una figura autoritaria que busca enfrentar "el maleficio", el cual trae consigo la intromisión de aves nocturnas, decidido y sin miedo. Incluso podemos apreciar que tiene un ademán corporal que denota que sólo él puede encarar la situación sin temor alguno, dejando atrás a los atemorizados sirvientes quienes permanecen detrás de él, apenas visibles pero presentes, con expresiones faciales de angustia y miedo. De esta manera podemos argüir, citando a Didi-Huberman, que "los pueblos están expuestos por el hecho de estar amenazados, justamente en su representación -política, estética- e incluso, como sucede con demasiada frecuencia, en su existencia misma." (Didi-Huberman, 2014: 11).

Figura 3. El progreso en acción

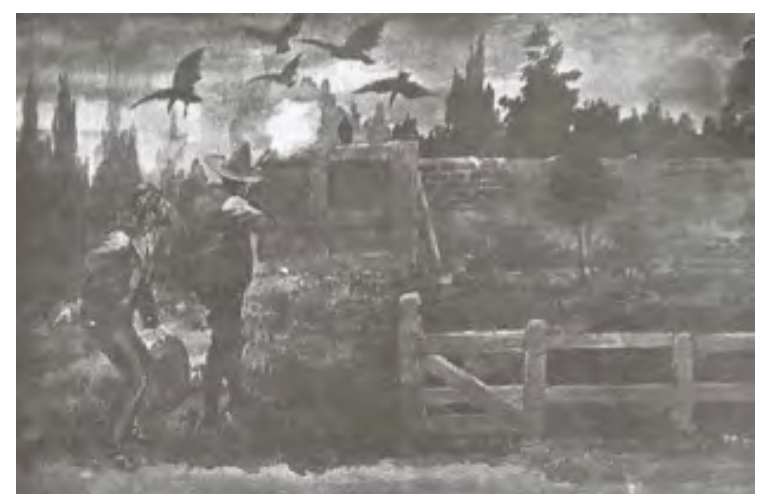

Fuente: adaptado de Othón, 2016: 36.

Como se menciona en el cuento, sólo la figura autoritaria posee el valor de emprender la búsqueda de la verdad y es sólo él quien tiene el valor de manejar armas. A su lado, se encuentra el acobardado y supersticioso administrador de la hacienda quien fue relegado de su estrato social por el estigma social de estar "maldito". Así, aunque es presa del miedo y de la "perdición" que lo aqueja, es sólo mediante la instrucción de la figura autoritaria que puede encarar el miedo, gracias a la intromisión del progreso, por el agente social quien lo incita o, mejor dicho, lo obliga a civilizarse.
Figura 4. La necesidad de civilizar

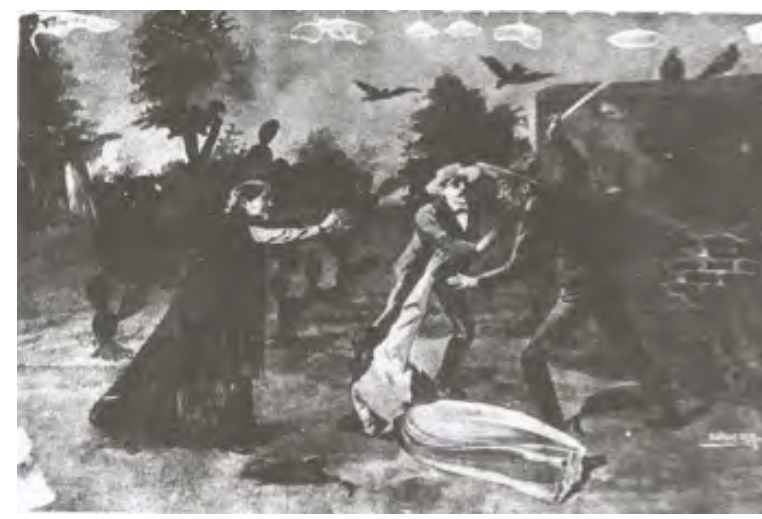

Fuente: adaptado de Othón, 2016: 39.

Esta cuarta imagen muestra cómo el personaje que encarna el progreso (el cual posee una expresión de serenidad, de cordura, así como un tono de piel más claro y una vestimenta propia de las élites) detiene a un frenético, envilecido $\mathrm{y}$ bestializado administrador de la hacienda que posee todos los vicios propios de los campesinos que deben ser erradicados, instándolo a no cometer un acto delictivo, para que no sea sancionado y forme parte del carácter unificador del progreso, a la par que lo insta a no utilizar la violencia física. Las mujeres tratan de protegerse en la imagen, pero es gracias al funcionario que el administrador no logra agredirlas. Nótense no sólo los ademanes, sino también la expresión del funcionario de disposición para enseñar, domesticar y civilizar frente al gesto del administrador de la hacienda, preso de las emociones "indecentes", irracionales y bárbaras que padece. Cabe destacar que ésta es la única imagen en que un personaje que encarna el progreso en Othón cuenta con una expresión facial suavizada, dispuesta a instruir y corregir.

\section{La noche y la oscuridad como factores que exacerban el miedo. Emociones y sentimientos a reprimir a favor del progreso en "Encuentro pavoroso" y "Coro de brujas"}

En los tres cuentos de Othón, en determinado momento, los narradores protagonistas se sienten presas del terror mientras buscan un sentido lógico a los sucesos sobrenaturales, pero lo justifican culpando al paisaje, a la noche y a la oscuridad. En "Coro de brujas" el funcionario que encara a las aves usadas para "el aquelarre" atribuye su miedo al paisaje al argumentar que "[a] la luz del día visto, habríame hecho reír; pero en aquel instante, lo confieso, sentí que se me erizaban los cabellos." (Othón, 2016: 37). Sin embargo, este personaje, enseguida recobra el sentido modernizador que debe civilizar a los campesinos y reprime sus 
emociones explicando que "[p]uesto ya en semejante trance, por mí mismo buscado, parecióme ridículo y vergonzoso retroceder, y arrojándome, de improviso, al fin de la aventura" (Othón, 2016: 37). Ello remite a las emociones que deben reprimirse en miembros de la élite, dado que es necesaria su intromisión del progreso para combatir las supersticiones del campesinado. El funcionario no sólo debe poner el ejemplo, también debe controlarse a sí mismo y erradicar ese obstáculo que puede entorpecer la domesticación de estos grupos excluidos, aún si el miedo es una emoción inherente al ser humano.

En "Encuentro pavoroso", el jinete se ve constantemente interrumpido por el recelo de su bestia de carga a continuar la jornada. Así, "el espanto que se apoderó de la cabalgadura, empezó a transmitirse a mis nervios [...] Entonces, y de improviso, el miedo, un miedo horrible me invadió. Sentí culebrear el terror por todos mis miembros" (Othón, 2016: 16). No obstante, hasta ese momento de la narración, el miedo se lo habían infundido amenazas reales, como serpientes y otras fieras temibles que surgieran en su andar nocturno. De esta manera, el paisaje en sí prepara el encuentro tenebroso como se puede apreciar en la siguiente ilustración.

Figura 5. La razón antepuesta a las emociones

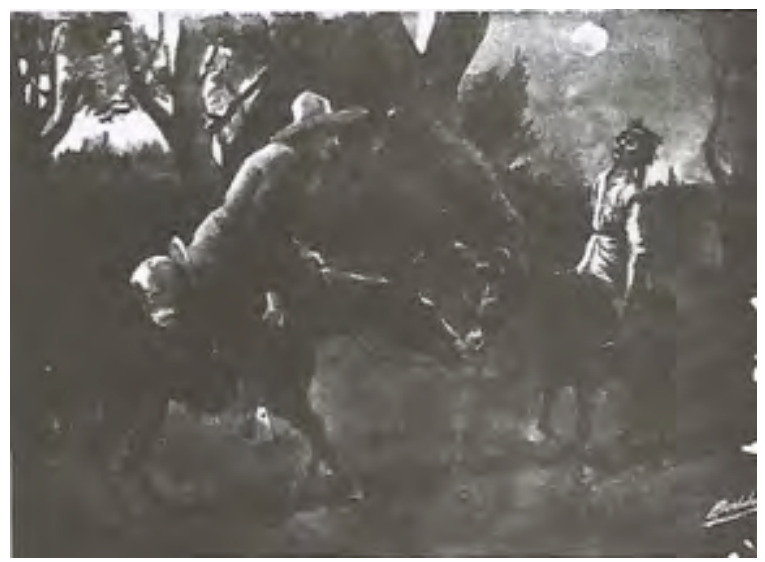

Fuente: adaptado de Othón, 2016: 19.

La figura 5 denota que, a pesar del miedo y el terror que invaden al jinete, él continúa su jornada y ve detenidamente al cadáver bajo la luz de la luna. Los ropajes del difunto dejan entrever que era un peón o un campesino, mientras que la vestimenta del jinete indica una jerarquía importante. Su expresión es de intriga y decisión al mirarle; incluso su mula, aunque recelosa, está avivada por el lúgubre contexto. Este personaje logra sobreponerse y huir del lugar. Cabe destacar que su miedo solamente se verá apaciguado gracias a que escuchará voces humanas.
Figura 6. Emociones y sentimientos reprimidos

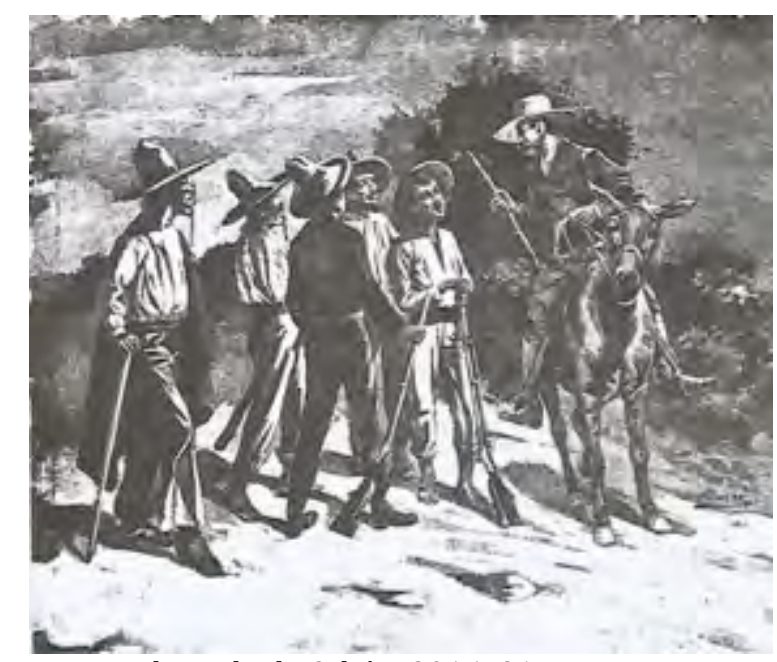

Fuente: adaptado de Othón, 2016: 21.

A pesar de que el jinete posee gran terror $y$ angustia, su miedo se ve menguado al encontrarse con un grupo de campesinos que charlan animadamente. Al saludarlos, cuidó "bien de hacerles conocer el horror pasado, que ellos seguramente, adivinaron en mi descompuesto semblante" (Othón, 2016: 21). Ello conlleva a la necesidad de reprimir no sólo sus emociones, también sus sentimientos ante unos desconocidos a los que considera como bárbaros poco inteligentes. El jinete, al platicar con los campesinos, se enteró de que la figura espectral con la que se encontró era en realidad un cadáver amortajado que se dirigía ante las autoridades. De esta manera, el narrador protagonista narra al público lector que "[a]l saber semejante cosa, encontradas sensaciones repentinamente de mí se apoderaban; ya era un anhelo brusco de abrazar, de agasajar a aquellos bárbaros, ya un furioso deseo de acometerlos. Contuve, sin embargo, tales ímpetus" (Othón, 2016: 22). Así, en la imagen, se puede apreciar al personaje (con la mezcla de sentimientos en su interior: alegría, miedo, júbilo y terror) con una expresión serena y un porte sobrio, quizá un tanto déspota ante los campesinos, quienes son ilustrados con expresiones faciales bonachonas y humildes que ven atentamente al jinete. Podemos apreciar también que la postura del jinete denota cierto poder al no soltar su arma y hacer un ademán con ella al dirigirse al grupo de individuos.

De esta manera, el miedo presente en estos personajes de Othón está ligado al paisaje y desarrolla su punto álgido en determinado momento de la narración (apariciones espectrales, sucesos sin explicación o figuras extrañas en el ambiente); antes de estos acontecimientos sólo sienten escepticismo y curiosidad al buscar la verdad de lo que sucede para demostrar que no existen acontecimientos sobrenaturales. Si bien, sí existe el miedo en sus personajes con autoridad, pero sólo lo comparten 
con el público lector; jamás lo dejan saber al campesinado. De acuerdo con Simonson, si una obra sugiere plantear y cuestionar las expectativas del público lector, entonces el autor es un historiador de la literatura, dado que apela al gusto de ciertos lectores, los cánones de la época, así como a la función y relación de sus textos con su público intelectual (Simonson, 2004: 184) a quienes dedicaba sus textos. Por ello, el papel del lector es importante, puesto que las obras literarias en sí ya contienen a sus posteriores lectores (Lanson, 2003b: 201). Estos cuentos, por ejemplo, el potosino los dedicó a José López Portillo y Rojas (1850-1923).

Si regresamos a uno de los hilos conductores de la presente investigación, lo civilizable, hasta este momento las imágenes y análisis de los cuentos han demostrado un campesinado visto con inferioridad, pero como bestias que pueden ser domesticadas y amaestradas. Ello les permite ser contemplados como agentes sociales a civilizar. Sin embargo, no todos los individuos pertenecientes a los estratos sociales desfavorecidos corrieron con la misma suerte, pues durante el porfiriato también permearon ideas concernientes al darwinismo social (Katz y Lomnitz, 2011: 25-26) y las obras de Othón no fueron la excepción. ¿Qué pasa entonces con aquellos personajes pertenecientes al sector rural que son demasiado antihigiénicos y sumamente faltos de inteligencia? ¿Pueden ser civilizados? Ello será analizado en el siguiente apartado.

\section{Los indomesticables o incivilizables. La muerte de aquellos que no pueden pertenecer al progreso en “Encuentro pavoroso" y "El nahual”}

Como se mencionó con anterioridad, las intromisiones del progreso representadas en los cuentos son obra de "un pasado presente, cuyos acontecimientos han sido incorporados y pueden ser recordados" (Koselleck, 1993: 338), experiencias mismas que Othón retomó de su contexto inmediato y de su pasado. De esta manera, sus narradores protagonistas remiten al progreso como una alusión de mejora social que logre acelerar el tiempo rural. No obstante, sus expectativas tienen una limitante porque "no es posible llegar a experimentarla." (Koselleck, 1993: 340). Esto puede ejemplificarse porque las expectativas de las figuras modernizadoras es introducir, enseñar y unificar a una sociedad rural para que sean parte de un país en progreso, pero ello ocasiona trabas con algunos personajes, ya sea porque no pueden eliminar la internalización de sus costumbres o bien, por su misma condición de marginalidad. Por consiguiente, los sectores más desfavorecidos son totalmente deshumanizados y erradicados gracias a su poca inteligencia o falta de higiene. Así, bajo la mirada y la pluma de Othón, los pueblos se ven amenazados a desaparecer (Didi-Huberman, 2014). De esta manera, el potosino destruyó a aquellos individuos que no pueden formar parte del progreso debido a las características que los hacen inferiores y los transforman en grandes obstáculos al progreso nacional. Por ejemplo, en "Encuentro pavoroso" se aniquilará al mozo alcohólico y supersticioso en exceso.

Figura 7. La servidumbre expuesta y perdida sin una guía que apele a la razón

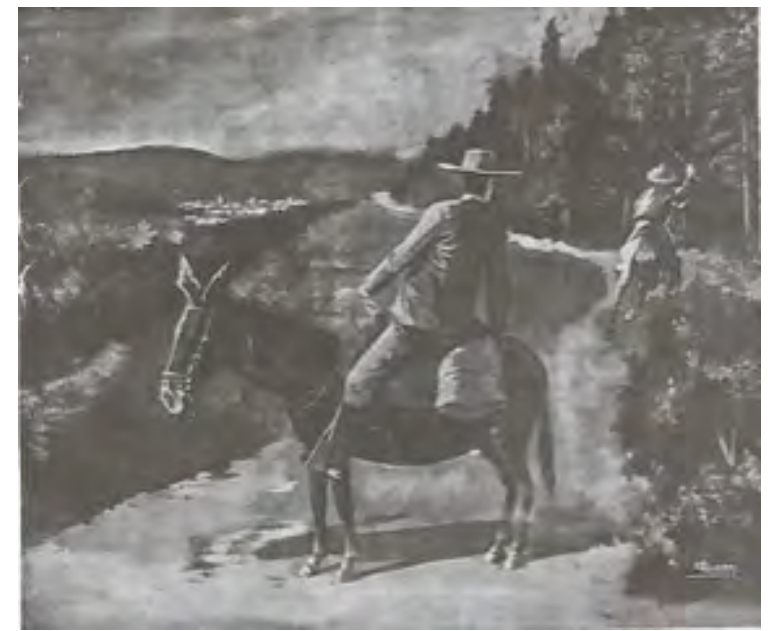

Fuente: adaptado de Othón, 2016: 13.

En esta séptima imagen observamos un mozo que emprende la carrera ante las órdenes del jinete. Este último lo observa galopar en medio de la noche. Al comienzo del cuento, el jinete continúa su jornada despacio para que el mozo le alcance. Sin embargo, la aparición del cadáver hace que huya del lugar apresuradamente. Posteriormente, se detalla la versión del personaje servil que lo acompañaba. Sin su amo, se refugió en bebidas embriagantes emprendiendo el camino alcoholizado, fumando cigarrillo tras cigarrillo. Cuando divisó el cadáver, se le acercó para que le encendiera un pitillo. Así, "su sorpresa y espanto fueron mayores mil veces que los que yo pasara, pues, montando un caballo que no se asustaba, y siendo supersticioso en extremo, como toda la gente campesina, fue brusquísimo y terrible el golpe moral que recibió su mezquino y desorganizado cerebro." (Othón, 2016: 22). El jinete detalla que el sirviente sí llegó a la villa donde estaba su amo, pero "cayó el desgraciado mancebo presa de mortal paludismo, que degeneró en una terrible fiebre cerebral. Pocas semanas después estaba muerto." (Othón, 2016: 23). Además, había enfrentado la aparición solo y alcoholizado. De esta manera, el sirviente es un ser indomesticable que muere gracias a que su cerebro no tuvo los medios para estructurar una lógica razonable ante tal "espectro", dentro de su superstición. Por ello, era un incivilizable, dado que en vano fueron "todos los empeños [del amo] que puse en arrancar de su ánimo tremenda impresión." (Othón, 2016: 23). Por 
consiguiente, el narrador protagonista no logró experimentar su expectativa (desaparecer la superstición del campesino afligido). Derivado de ello, se destruye al personaje, ya que fueron sus supersticiones y vicios lo que lo llevaron a la muerte.

En "El nahual" el caso es similar, solo que el sector social se sitúa un peldaño más abajo, remitiendo a los mendigos y vagabundos

Figura 8. Lo civilizado ante lo que amerita morir

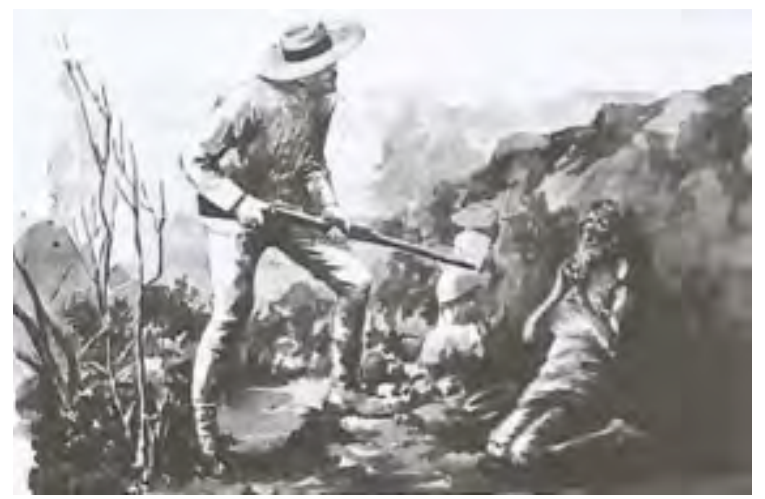

Fuente: adaptado de Othón, 2016: 52.

En la figura 8 podemos ver cómo se enfrenta el progreso ante uno de los estratos más bajos de una sociedad: los mendigos. El agente modernizador apunta con su arma a un individuo al que ha despojado de toda humanidad y civilidad no solo por su apariencia, también por ser un supuesto delincuente. El viejecillo ruega por su vida, auxiliándose en la religión y en sus dolencias (apelando a la lástima) para que no le maten. Así, en la imagen observamos cómo el mendigo está arrinconado y de rodillas implora para que lo deje vivir. Está retratado como un ser andrajoso y lastimero. El personaje que desea matarlo y golpearlo, al oír sus súplicas, lo deja vivir, dado que le despierta compasión, además de que "[u]na ola de sangre fría hízome volver el buen sentido, tan repentinamente como me había abandonado." (Othón, 2016: 52). De esta manera, no lo asesina, pero el estilo de vida que lleva el viejecillo será lo que lo lleve a la muerte al no formar parte del progreso.

Figura 9. La erradicación de lo nocivo y peligroso

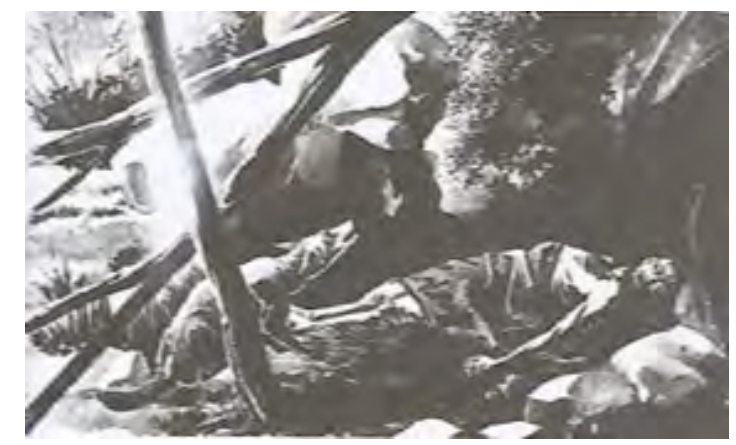

Fuente: adaptado de Othón, 2016: 55.
En el cuento sólo logran encontrar al mendigo muerto en lo profundo de una montaña, en medio de condiciones sumamente terribles. En esta imagen podemos apreciar el cadáver del viejecillo. Reducido a un mero ser vivo, no es considerado como un ser humano al no ser domesticado ni civilizado. La única humanidad representada es el cariño, sufrimiento y fidelidad del coyote amaestrado que aúlla la ausencia de su amo. El narrador protagonista definirá la vida del nahual como una "miserable existencia" (Othón, 2016: 55) y por ello destruye su vida al no tener cabida en el progreso porfiriano haciéndolo desaparecer. Paradójicamente, el mendigo recupera una importancia social gracias a su muerte, ya que solo dejando de existir se le toma en cuenta como ser humano por la lástima y ternura de aquellos lugareños que sí se pueden civilizar, quienes le fraguaron un entierro digno (Othón, 2016: 55). Cabe destacar que dichos sentimientos fueron similares a los que despertó en el personaje civilizado y que no fueron reprimidos. De esta manera, sólo mediante la existencia de los sentimientos de los otros el mendigo logra no ser asesinado, pues finalmente su estilo de vida lo lleva a morir y solo como cadáver será tratado como una persona.

\section{Reflexiones finales}

Con los cuentos e imágenes previamente analizadas, vale la pena destacar lo dicho por Michel de Certeau acerca del progreso en una entrevista: el autor de una obra está dentro de una operación de carácter antropológico pues al recuperar fragmentos del pasado en sus textos, se pretende transformar una sociedad (De Certeau citado en Carbó y Giraud, 1982: s/p). Dicho lo anterior, debemos señalar que Othón en sus obras deja claro que sus relatos son acontecimientos pasados los cuales representó textual y visualmente. En estos cuentos mostró una mirada al campesinado porfiriano por la élite. De esta manera, el potosino recurrió a los fragmentos de su pasado para elaborar una narrativa con la función de indicar los obstáculos que dificultaban el progreso de la nación mexicana, premisas que flotaban en su ambiente literario y político. Para ello, suponemos, remitió a la elaboración de temporalidades y periodizaciones construidas en su presente las cuales, al ser subjetivas, reflejaban los problemas, necesidades y funciones de corte sociopolítico (Hernández Fuentes et. al., 2017: 20-21) que vislumbró la élite potosina: escritores, intelectuales y políticos que aceptaban y consensuaban las ideologías del racismo, clasismo y darwinismo social. De esta manera, Othón no sólo ejemplificó dichos tópicos, también plasmó su propia interpretación de las singularidades que observó y presenció (Hernández Fuentes et. al., 2017: 20-21), ideas mismas que pudo haber compartido -y reproducido- con su círculo cercano, 
pues el autor formó parte de una élite intelectual, una sociedad burguesa que logró que su escritura se trasladara (De Certeau citado en Carbó y Giraud, 1982: s/p) a públicos sucesivos como la opinión pública. Prueba de ello es que Othón dedicó sus cuentos a José López Portillo y Rojas, pero también se publicaron en El Mundo Ilustrado, es decir también fue dirigida a nuevos lectores. En la actualidad, podemos abordar sus obras como un fenómenos o hechos sociales los cuales ya contienen a un público lector en donde nosotros (así como generaciones anteriores y posteriores) leemos a Othón con otros enfoques, perspectivas y necesidades, lo que Lanson llama la evolución de un libro (2003b: 201-207).

En la presente investigación hemos logrado acercarnos no sólo a la narrativa de Othón, también a sus ideales y expectativas, así como a aquellas particularidades y generalidades del Porfiriato de los primeros años de siglo XX. Hemos detectado, en sus obras literarias y en sus ilustraciones, las premisas que permeaban hacia los sectores sociales que debían integrarse a la nación para trabajarla y sacarla avante, pues, a pesar de la fobia y la repulsión a estos estratos, era necesario controlarlos al mismo tiempo que debía embellecerse el territorio mexicano. Esto se reflejó en los cuentos del autor y en las ilustraciones que los acompañan, elaboradas con una finalidad y una intencionalidad. Por ello, creemos que Othón sí logra acercarse, aunque con repelencia, al campesinado porfiriano delimitando quién sí y quién no podía -y debía- civilizarse, determinando los diferentes grados de obstáculos que representaban para el progreso. De esta manera, Othón desapareció a los más deleznables, pero al mismo tiempo no desapareció a los necesarios para construir, desde abajo, la nación.

Asimismo, este trabajo es un esfuerzo por rescatar algunas visiones que pueden ayudar a comprender cómo eran contemplados, por las élites, los campesinos durante el Porfiriato en el momento que se estaba cimentando y construyendo la nación mexicana, mismos que pueden hacernos reflexionar para entender cómo se ve este sector social en la actualidad. Finalmente, cabe señalar que es un acercamiento a algunos de los elementos que pueden reconstruirse, analizarse y estudiarse en el autor potosino, pero también podemos trazar una línea que marca la evolución de sus obras en el siglo XXI. Sin embargo, ello no determina la correcta lectura de sus textos ni pone punto final a los debates que pueden suscitarse posteriormente, puesto que se debe prestar atención a los diferentes enfoques multidisciplinarios para abordar un objeto de estudio, quiénes construyen la historia, la historiografía o la historia literaria. Sería interesante, por ejemplo, escudriñar la recepción inicial de sus cuentos y novelas; su trayectoria intelectual; analizar otras particularidades sociohistóricas que detalló el escritor; estudiar las condiciones sociales, políticas, económicas, culturales (véase De Certeau, 2010: 69-86), -así como sus redes intelectuales- que hicieron posible su producción literaria y nos ayude a entenderlo como individuo antes de ser el gran poeta consagrado, sin caer en una biografía cargada de juicios de valor.

La metodología utilizada nos permitió elaborar un análisis más flexible de lo que experimentamos con la lectura y sus imágenes, al mismo tiempo que nos invitó a reflexionar desde dónde leemos sus obras, con qué finalidades y necesidades las analizamos ahora, pues hacia 1953 José Luis Martínez aseguró que durante el siglo XIX se produjo una basta literatura mexicana en donde varios escritores, como Othón, debían retomarse en su presente, ya que contaban con "estudios parciales" (Martínez, 1953: 356-357). A más de cincuenta años de lo redactado por Martínez, creemos que la multi e intradicisplinariedad pueden contribuir a proponer y elaborar enfoques novedosos de este autor que nos involucren en nuevas tareas de la historia literaria othoniana. 


\section{Referencias}

Anaya, J. (1999). La dramaturgia de Manuel José Othón, en el olvido porque en ella se revela crítico mordaz. En: La Jornada. Disponible en https://www.jornada.com.mx/1999/06/28/cul-othon.html Consultado el 30 de julio de 2019.

Alatorre, A. (1973). ¿Qué es la crítica literaria? Revista de la Universidad de México, 9, 1-7. Disponible en http://www.revistadelauniversidad.unam.mx/ojs_rum/index.php/rum/article/view/9846/11084 Consultado el 29 de julio de 2019.

Betancourt, I. (2016). El verdadero Othón, no el de los monseñores. En: La Jornada San Luis. Disponible en https://lajornadasanluis.com.mx/opinion/verdadero-othon-no-los-monsenores/ Consultado el 30 de julio de 2019.

Carbó, C. y François G. (1982). Entrevista a Michel de Certeau-primera parte. Disponible en http://www.elseminario.com.ar/biblioteca/Carbo_Giraud_entrevista_decerteau.htm Consultado el 12 de febrero de 2019.

De Certeau, M. (2010). La operación historiográfica. En: La escritura de la historia (pp. 67-118). México: Universidad Iberoamericana.

Didi-Huberman, G. (2014). Parcelas de humanidades. En: Pueblos expuestos, pueblos figurantes (pp. 11-50). Buenos Aires: Manantial.

Easterling, S. (2011). Gender and poetry Writing in the Light of Mexico's Liberal Victory, 1867-ca. 1890. Mexican studies/Estudios mexicanos, 27(1), 97-142. DOI: 10.1525/msem.2011.27.1.97

Foucault, M. (2008). Seguridad, territorio y población. España: Akal.

González, M. P. (s/f). Algunas influencias perceptibles en la obra de Othón. Disponible en https://www.bcn.cl/obtienearchivo?id=documentos/10221.1/44371/1/192318.pdf\&origen=BDigital Consultado el 30 de julio de 2019.

Granados, P. (2010). Introducción. En: P. Granados (coord.), El ocaso del Porfiriato (pp. 19-48). México: FLM/FCE. Hernández Castillo, D. (2018). El cuerpo como instrumento para violentar y humillar en el cuento "El pastor Corydón" de Manuel José Othón. Tenso Diagonal, 5, 125-131. Disponible en http://www.tensodiagonal.org/TD05/TensoDiagonal05-ZC-Hernandez.pdf Consultado el 20 de enero de 2019.

- (2019a) Exclusión y darwinismo social en Manuel José Othón. La falta de higiene como degeneración en un personaje del cuento El Nahual. Ponencia del III Encuentro Internacional de Investigación HistóricoLiteraria (21 al 24 de mayo). La Paz, Baja California Sur.

- (2019b) "La noche de las brujas". El aquelarre mexicanizado en Manuel José Othón. Trabajo terminado y aceptado como ponencia virtual a presentarse en el I Congreso Internacional de Artes y Culturas 2019.

Hernández Fuentes, M. (et. al). (2017). El campo de la historiografía. Inducción. México: DCSH, Posgrado en Historiografía, UAM-A.

Katz, F. y Lomnitz C. (2011). El porfiriato y la Revolución en la historia de México. México: ERA.

Koselleck, R. (1993). "Espacio de experiencia” y "Horizonte de expectativa" dos categorías históricas. Futuro pasado. Para una semántica de los tiempos históricos (pp. 333-357). Barcelona: Paidós.

Lanson, G (2003a). El método de la historia literaria. Literatura: teoría, historia, crítica, 5, 163-194. DOI:10.15446/lthc

- (2003b). La historia literaria y la sociología. Literatura: teoría, historia, crítica, 5, 195-118. DOI:10.15446/lthc

Leal, L. (1958). Los sonetos de Manuel José Othón. La palabra y el hombre. 6, 183-198. Disponible en https://cdigital.uv.mx/handle/123456789/3249 Consultado el 30 de julio de 2019.

Lutz, B. (2009). El Estado y los campesinos: evolución de los mecanismos de vigilancia y castigo en el siglo XX. En: G. Ávalos Tenorio, El Estado mexicano, (pp. 149-191). México: UAM-X.

Martínez, J. L. (1953). Tareas para la historia literaria de México. Historia Mexicana, 2(3), 353-370. Disponible en https://historiamexicana.colmex.mx/index.php/RHM/article/view/493 Consultado el 2 de agosto de 2019.

Mendieta. E. (2007). "Hacer vivir y dejar morir": Foucault y la genealogía del racismo. Tabula rasa, 6, 138-152. DOI: doi.org/10.25058

Modernización. Disponible en: http://www.eumed.net/diccionario/definicion.php?dic=3\&def=386 Consultado el 18 de enero de 2019.

Montejano y Aguiñaga, R. (1997). Manuel José Othón y su ambiente. México: Universidad Autónoma de San Luis Potosí.

Othón, M. J. (2016). Cuentos de espantos y novelas rústicas. México: Fontamara.

París Pombo, M. D. (2009). Racismo institucional, discriminación y exclusion en México. En: G. Ávalos Tenorio, El Estado mexicano, (pp. 193-216). México: UAM-X.

Peñalosa, J. A. (1995). Introducción. En: M. J. Othón, Cuentos completos de Manuel José Othón, (7-53). México: Universidad Autónoma de San Luis Potosí. Disponible en http://ninive.uaslp.mx/jspui/bitstream/i/3158/2/ceu0107.pdf Consultado el 18 de enero de 2019.

Reyes, A. (1910). Los poemas rústicos de Manuel José Othón. México: Lacaud. 
Simonson, P. (2004). Cuando la literatura escribe la historia literaria. Literatura: teoría, historia, crítica, 6, 183219. DOI:10.15446/lthc

Uribe Soto, M. L. (2016). Prostitutas, rateras y pulqueras. México: Universidad Autónoma de San Luis Potosí/CENEJUS.

Wedel, A. (2000). La presencia alemana en el romanticismo de Hispanoamérica. Delaware Review of Latin American Studies, 1(2), s/p. Disponible en http://udspace.udel.edu/bitstream/handle/19716/19493/Vol1-2Wedel.pdf?sequence=3\&isAllowed=y Consultado el 7 de agosto de 2019. 